ISSN: 2224-0616

Int. J . Agril. Res. Innov. \& Tech. 1(1\&2): 9-15, December, 2011 Available online at http://www.ijarit.webs.com

\title{
EFFECT OF LIME, MAGNESIUM AND BORON ON WHEAT (Triticum aestivum L.) AND THEIR RESIDUAL EFFECTS ON MUNGBEAN (Vigna radiata L.)
}

\author{
Akbar Hossain ${ }^{*}$, M.A.Z. Sarker2, M.A. Hakim³, Mst. T. Islam and M.E. Ali ${ }^{5}$ \\ Received 13 August 2011, Revised 23 September 2011, Accepted 25 December 2011, Published online 31 December 2011
}

\begin{abstract}
The study was carried out during 2007-2008 season in the research field of Wheat Research Centre, Bangladesh Agricultural Research Institute, Dinajpur to know the effect of lime, Magnesium (Mg) and Boron (B) on yield and yield components of wheat and also their residual effect on mungbean. The geographical position of the area is between $25^{\circ} 62^{\prime} \mathrm{N}$, $88^{\circ} 63^{\prime} \mathrm{E}$ and 38.20 meter above sea level. The experiment was laid out in Randomized Complete Block Design with three replications, both in wheat and mungbean. Treatments for wheat were (I) recommended fertilizer $+\mathrm{Mg}+\mathrm{B}$, (II) recommended fertilizer + lime + B + Mg, (III) recommended fertilizer + lime + Mg, (IV) recommended fertilizer + lime + B and (V) control (Only recommended fertilizer) and for mungbean were (I) recommended fertilizer $+\mathrm{Mg}+\mathrm{B}$, (II) $75 \%$ of recommended dose, (III) recommended fertilizer $+\mathrm{B}$, (IV) recommended fertilizer $+\mathrm{Mg}$ and $(\mathrm{V})$ control (without fertilizers). Results showed that the highest yield and yield components of wheat were recorded from recommended fertilizers + lime $+\mathrm{B}+\mathrm{Mg}$ treated plot and the second highest were recorded from recommended fertilizers + lime + Mg treated plot. The lowest was recorded in control plot (only recommended fertilized). In case of mungbean the highest was found from recommended fertilizers $+\mathrm{B}$ treated plot, this treatment was limed in previously cultivated wheat crop and the lowest was recorded from control plot (without fertilizer).
\end{abstract}

Keywords: Wheat, Residual Effect, Mungbean, Magnesium, Lime and Boron

\footnotetext{
${ }^{1,2 \& 3}$ Wheat Research Centre, Bangladesh Agricultural Research Institute, Nashipur, Dinajpur-5200, Bangladesh.

${ }^{4}$ Assistant Registrar, Academic and Scholarship Division, HSTU, Dinajpur-5200, Bangladesh

${ }^{5}$ Soil Science Division, Bangladesh Agricultural Research Institute, Joydebpur, Gazipur, Bangladesh

*Corresponding author's email: tanjimar2003@yahoo.com
}

Reviewed by Mirza Hasanuzzaman, Sher-e-Bangla Agricultural University, Bangladesh

\section{Introduction}

Acid soil is the type of soil in which the quantity of free $\mathrm{H}^{+}$ions is higher than that of alkali or alkaline earth cations. Most of the soils of Bangladesh are low to medium acid in reaction, due to the predominance of high rainfall areas and leaching. There are mainly three groups of acid soils found in Bangladesh, such as: acid basin clay, acid sulphate soil and brown hill soil (Alam, 2006). In northern part of Bangladesh is covered by acid sulphate soil and it is an additional problem to cultivation, due to deficiencies of molybdenum (Mo) and boron (B), and toxicities of aluminum (Al) , manganese (Mn) or hydrogen ion $\left(\mathrm{H}^{+}\right)$(Marufuzzaman et al., 2010). On most acid soils, there are several limiting factors for plant growth, including toxic levels of $\mathrm{Al}, \mathrm{Mn}$, and iron $(\mathrm{Fe})$, as well as deficiencies of some essential elements, such as phosphorus $(\mathrm{P})$, nitrogen $(\mathrm{N})$, potassium $(\mathrm{K})$, calcium $(\mathrm{Ca}), \mathrm{Mg}$, and some micronutrients (Kochian et al., 2004). Among these constraints, $\mathrm{Al}$ toxicity and $\mathrm{P}$ deficiency are the most important due to their ubiquitous existence and overwhelming impact on plant growth (Kochian et al., 2004).

Soil $\mathrm{pH}$ is one of the most important soil properties that affect the availability of nutrients. Macronutrients tend to be less available in soils with low $\mathrm{pH}$. Micronutrients tend to be less available in soils with high $\mathrm{pH}$. Lime can be added to the soil to make it less sour (acid) and also supplies calcium and magnesium for plants to use (NCDACS, 2011). Rahman et al. (2002) reported that application of lime influenced the nutrient availability of soil, resulting increased the yield and yield components of both anaerobic rice and yearly aerobic wheat cropping system. 
Magnesium is the central core of the chlorophyll molecule in plant tissue. If $\mathrm{Mg}$ is deficient, the shortage of chlorophyll results in poor and stunted plant growth. The foliar application of zinc (Zn), K or Mg had a positive effect on growth parameters, yield and yield components of mungbean was reported by Thalooth et al. (2006). Kassab (2005) indicated that foliar application of $\mathrm{Zn}, \mathrm{Mg}, \mathrm{Mn}$ and Fe significantly increased growth parameters, yield and its components of mungbean plants.

Boron, a micro-nutrient, is essential for pollen viability and seed production of crops as well as flowering and fruiting and it plays a vital role in nitrogen metabolism, hormonal action and cell division (BARI, 2006). Boron availability in soils is very much depending on soil reaction $(\mathrm{pH})$. The effect of liming on reducing $B$ availability to plants is well known in agricultural crops, and it is at least partly caused by increased absorption of B in the soil as the $\mathrm{pH}$ increased (Gupta et al., 1985). They also reported the influence of $B$ fertilizers depends strongly on the soil types, because $\mathrm{B}$ adsorption varies between different soils.

Residual effect of fertilizers is very important for economical crop production. It is defined as the proportion of the fertilizer nutrient that remains in the soil and stays effective after the season of application. This assumption is also supported by Rowell (1994) and Warren (1992). Srisa-ard (2007) reported that residual effects of applied chemical fertilizers to main crops of soybean gave better growth and seed yields of sunflower plants and it is considered to be the first choice. He also stated the use of sunflower and maize as main crops gave a second choice for subsequent crop of sunflower. The residual effect of lime significantly increased soil pH to 4.8 and 5.0 respectively, in the second season and also significantly increased exchangeable $\mathrm{Mg}$ from 0.10 to $0.30 \mathrm{cmolckg}^{-1}$ (ZARI, 2011). Fatell et al. (2007) found residual effect of lime significantly increased crop yield up to four years. Grain and haulm yields of residual crop greengram were significantly influenced by the residual effect of boron applied to the previous crop (Renukadevi et al., 2004). Magnesium fertilizer residues slightly increased grass yields in the one season, but not later. However, \% Mg in the grass dry matter was increased by the residues for the whole 7-5 year period. Exchangeable Mg was also increased in soil sampled after the final harvest, especially in the 23-46 cm subsoil (Bolton and Penny, 2009).

It was reported that the cropping sequence can help to reduce the level of nitrate sensitivity to soil that will affected the rate of biological nitrogen fixation (Peoples et al., 1995a). When a legume is sown immediately after a cereal, it might fix more
$\mathrm{N}_{2}$ as compared to when it is grown immediately after another $\mathrm{N}_{2}$-fixing legume, because the level of soil nitrate will be low when the preceding crop is a cereal (Peoples et al., 1995b).

Cropping sequence and crop responses to lime, B and $\mathrm{Mg}$ and their residual effects on proceeding crops are still unknown of a major part of northern Bangladesh. Considering the above facts, the present study has been undertaken to know the effect of lime, $\mathrm{Mg}$ and $\mathrm{B}$ on yield and yield components of wheat (Triticum aestivum L.) and their residual effect on mungbean (Vigna radiata $\mathrm{L}$.).

\section{Materials and Methods}

\section{Experimental site for both wheat and mungbean}

The study was carried out in Rabi (Winter) and Kharif-1 (Summer) seasons of 2007-2008 in the research field of Wheat Research Centre, Bangladesh Agricultural Research Institute (BARI) Nashipur, Dinajpur, Bangladesh. The Agro Ecological Zone (AEZ) of the area is Old Himalayan Piedmont Plain (AEZ-1) (FAO/UNDP, 1988). The geographical position of the area is between $25^{\circ} 62^{\prime} \mathrm{N}, 88^{\circ} 63^{\prime} \mathrm{E}$ and 38.20 meter above sea level. The soil of the experimental plot was sandy loan and reaction is acidic (Table 1). The experimental site was covering about $21 \%$ wheat areas of the country, for suitable weather (comparatively cooler and longer winter) (Bodruzzaman, et al., 2005).

\section{Experimental procedures for wheat}

The experiment was laid out in Randomized Complete Block Design with 3 replications. For wheat treatments were (I) recommended fertilizer $+\mathrm{Mg}+\mathrm{B}$, (II) recommended fertilizer + lime + B + Mg, (III) recommended fertilizer + lime + Mg, (IV) recommended fertilizer + lime + $\mathrm{B}$ and (V) control (Only recommended fertilizer). Unit plot size was $5 \times 4 \mathrm{~m}$. For liming, $\mathrm{CaCO}_{3}$ was applied in treatment wise at the rate of $2 \mathrm{t}$ ha-1 and irrigation was done immediately after application. $\mathrm{Mg}$ and $\mathrm{B}$ were applied treatment wise at the rate of 10 and $1 \mathrm{~kg} \mathrm{ha}^{-1}$, respectively.

For wheat experiment variety Prodip (BARI Gom-24) was used. Seed was treated with Provax-200 WP an effective seed treating fungicide, consisting of Carboxin and Thiramon. Sowing was done on 04 December 2007 in lines $20 \mathrm{~cm}$ apart at a seed rate of $140 \mathrm{~kg} \mathrm{ha}^{-1}$. Recommended fertilizer dose for wheat was 12035-50-20-4 kg ha- ${ }^{-1} \mathrm{~N}-\mathrm{P}-\mathrm{K}-\mathrm{S}-\mathrm{Zn}$. Two-third of N and full amount of other fertilizers were applied as basal during final land preparation. Rest 1/3 of $\mathrm{N}$ fertilizer was applied after first irrigation on 21 days after sowing (DAS). Second and third irrigations were given at booting (47 DAS) and 
grain filling (78 DAS) stage. Weeds were controlled by spraying 2, 4-D Amine on 30 DAS. Other intercultural operations were done properly. The crop was harvested plot-wise at full maturity. Plots were harvested for wheat $3 \mathrm{~m}$ long middle 19 rows $(3 \times 4 \mathrm{~m})$, for avoiding boarder effect. The sample plants were harvested separately. The harvested crop of each plot was bundled separately, tagged and taken to threshing floor. The bundles were thoroughly dried in bright sunshine, weighed and threshed respectively.

\section{Data on wheat experiment}

Data on plants $\mathrm{m}^{-2}$ (no.), tillers $\mathrm{m}^{-2}$ (no.), spikes $\mathrm{m}^{-2}$ (no.), plant height at maturity $(\mathrm{cm})$, spike length $(\mathrm{cm})$, Spikelets spike-1 (no.), grains spike-1 (no.), 1000-grain weight (g), straw yield (t ha-1), grain yield (t ha-1) and harvest index (\%)were recorded. Grain yield was adjusted to $12 \%$ moisture. The harvest index (\%) was calculated according to the following formula.

Harvest index $(\%)=$ Grain yield $/$ Biological yield (grain yield + straw yield) $\times 100$

\section{Experimental procedures for mungbean}

After harvested of wheat mungbean was grown in the same plots. Treatments for mungbean experiment were- (I) recommended fertilizer + $\mathrm{Mg}+\mathrm{B}$, (II) $75 \%$ of recommended dose, (III) recommended fertilizer $+\mathrm{B}$, (IV) recommended fertilizer $+\mathrm{Mg}$ and (V) control (without fertilizers). According to the research finding (Fatell et al., 2007), it was assumed that the effect of liming would continue at least for the next crop. For this reason liming was not done before mungbean. The recommended dose of fertilizers for mungbean as 20-20-30-10-4 $\mathrm{kg} \mathrm{ha}^{-1} \mathrm{~N}-\mathrm{P}-\mathrm{K}-\mathrm{S}$ $\mathrm{Zn}$. Mg and B were applied treatment wise at the same rate for wheat. All the fertilizers were applied as basal during final land preparation.
Variety BARI Mug-6 was sown on 11 April 2008 at a seed rate of $30 \mathrm{~kg} \mathrm{ha}^{-1}$ in lines $30 \mathrm{~cm}$ apart. The light irrigation was done just after sowing. Thinning was done on 11 DAS. Weeding was done 24 DAS. Insecticide was applied 2 times. Other intercultural operation was done when necessary. Crop was harvested at full maturity.

\section{Data on mungbean}

Data on plants $\mathrm{m}^{-2}$ (no.), plant height at harvest $(\mathrm{cm})$, Fresh weight of plants $\mathrm{m}^{-2}(\mathrm{~g})$, pods plant ${ }^{-1}$ (no.), pod length (cm), seeds pods ${ }^{-1}$ (no.), 1000grain weight $(\mathrm{g})$, biological yield $\left(\mathrm{t} \mathrm{ha}{ }^{-1}\right)$ and grain yield ( $\mathrm{t} \mathrm{ha}^{-1}$ ) were recorded.

\section{Data on soil}

Soil $\mathrm{pH}$ was measured immediately before liming, and 56 and 70 Days after liming (i.e. 42 and 56 DAS). Soil $\mathrm{pH}$ was measured in a 1:2 soil/water using glass electrode $\mathrm{pH}$ meter. Organic carbon was determined by Walkley and Black oxidation method (Walkley and Black, 1934), total $\mathrm{N}$ was determined by micro Kjeldhal method (Jackson, 1958). Ca and Mg were determined by extractable method (Hunter, 1972), P, K, S and Zn were determined by modified Hunter's methods (BARC, 1984) B was determined colorimetrically by the AzomethineH method (Sippola and Ervio, 1977).

\section{Data analysis}

Data were complied and subjected to statistical analysis. Analysis of variance (ANOVA) was done and means separation was done according to Duncan's New Multiple Range Test (Gomez and Gomez, 1984).

\section{Results and Discussion}

The results of pre-seeding soil analysis indicated that soil $\mathrm{pH}$ of the experimental site was 4.46 and organic matter content was $1 \%$ (Table 1).

Table 1. Soil analysis report of experimental field before liming

\begin{tabular}{|c|c|c|c|c|c|c|c|c|c|c|}
\hline \multirow[t]{2}{*}{ Items } & \multirow[t]{2}{*}{$\mathrm{pH}$} & $\begin{array}{l}\text { Organic } \\
\text { matter }\end{array}$ & Total N & $\mathrm{Ca}$ & $\mathrm{Mg}$ & K & $\mathrm{P}$ & $\mathrm{S}$ & B & $\mathrm{Zn}$ \\
\hline & & & $\%$ & \multicolumn{3}{|c|}{ Meq $100 \mathrm{~g}^{-1}$ soil } & \multicolumn{4}{|c|}{$\mu \mathrm{g} \mathrm{g}^{-1}$ soil } \\
\hline Present status & 4.46 & 1.0 & 0.05 & 0.80 & 0.40 & 0.07 & 15.00 & 13.00 & 0.13 & 1.41 \\
\hline Critical level & - & - & 0.12 & 2.0 & 0.80 & 0.20 & 14.00 & 14.00 & 0.20 & 2.00 \\
\hline Interpretation & Acidic & Low & Very low & Low & Low & Low & High & Low & Low & Low \\
\hline
\end{tabular}

Total $\mathrm{N}$ was $0.05 \%$ which was much below at reaction of soil was acidic. It was observed that critical level i.e. the soil was very deficient in $\mathrm{N}$ soil $\mathrm{pH}$ increased after liming in the liming content. Based on critical level of these plant treated plots (Table 2). Soil pH of untreated plots nutrients $\mathrm{Ca}, \mathrm{Mg}, \mathrm{K}, \mathrm{S}, \mathrm{B}$ and $\mathrm{Zn}$ were low, but $\mathrm{P}$ was also increased, but increment was lower was high. On an average, the soil was deficient in compared to lime treated plots.

nitrogen and other element except available $\mathrm{P}$ and

Table 2. Changed soil pH after limed compared with initial

\begin{tabular}{ll|lc}
\hline \multirow{2}{*}{ Lime and fertilizers for wheat } & Initial soil pH & pH at 42 DAS & pH at 56 DAS \\
\cline { 2 - 4 } & Before liming & & After liming \\
\hline Recommended fertilizer +B +Mg & 4.50 & 4.52 & 4.97 \\
Recommended fertilizer + lime +B + Mg & 4.40 & 5.87 & 6.02 \\
Recommended fertilizer + Mg +lime & 4.30 & 5.80 & 6.05 \\
Recommended fertilizer + B +lime & 4.50 & 5.71 & 5.97 \\
Control (only recommended fertilizer). & 4.20 & 4.37 & 4.61 \\
\hline
\end{tabular}




\section{Yield and yield components of wheat}

Yield and yield components of wheat were significantly influenced by lime, $\mathrm{Mg}$ and $\mathrm{B}$ application (Table 3). Plant population per $\mathrm{m}^{2}$ was similar in all the plots. The highest number of tillers and spikes per $\mathrm{m}^{2}$, and plant height were obtained from recommended fertilizer + lime + $\mathrm{Mg}+\mathrm{B}$ treated plot, which was at par with recommended fertilizer + lime $+\mathrm{Mg}$ and recommended fertilizer + lime $+\mathrm{B}$. The lowest was recorded from only recommended fertilizer treated plot. Spike length of wheat plays an important role in the number of grains per spike and ultimately the yield. Spike length of wheat mainly controlled by the genetic make up of a genotype and also environmental factors (Islam, 1995). The longest spike and highest number of spikelets spike ${ }^{1}$ were obtained from recommended fertilizer + lime $+\mathrm{Mg}+\mathrm{B}$ and the second highest was recorded from recommended fertilizer + lime $+\mathrm{Mg}$ and recommended fertilizer + lime B. The shortest spike was resulted from only recommended fertilizer treated plot. Number of grains spike ${ }^{-1}$ is very important parameter contributing grain yield. Number of grains spike-1 depends on the length of spike and it is determined by genetic make up and growth factors prevailing during the growth period (Islam, 1995). Number of grains spike ${ }^{-1}$ has a direct bearing on the final grain yield in wheat and varies with growing conditions. The maximum grains spike $^{-1}$ was found from recommended fertilizer + lime $+\mathrm{Mg}+\mathrm{B}$ treated plot which was at par recommended fertilizer + lime B treated plot. The second highest grains spike $^{-1}$ was recorded from recommended fertilizer $+\mathrm{Mg}+\mathrm{B}$ and recommended fertilizer + lime B treated plot. The lowest grains spike was resulted from recommended fertilizer treated plot. Thousand grain weight of wheat is one of the most important yield contributing characters of wheat for good yield. The heavier 1000-grains weight found when the crop treated with recommended fertilizer + lime $+\mathrm{Mg}+\mathrm{B}$ which was statistically similar with recommended fertilizer + lime B. The lowest 1000-grains were resulted from recommended fertilizer treated plot. Straw yield was the highest when application of recommended fertilizer + lime + $\mathrm{Mg}+\mathrm{B}$. The second highest straw yield was obtained recommended fertilizer + lime B treated plot which was similar to recommended fertilizer + lime $+\mathrm{Mg}$ and the lowest was recorded from recommended fertilizer treated plot. Kumer et al. (1994) reported that the straw yield decreased probably due to the fact that plant got unfavorable growing condition at vegetative stage, as a result became thinned and produced fewer tillers which in turn decreased the straw yield. On the other hand, grain yield of wheat significantly affected by different treatments. It was reported that the highest grain yield was found when the crop grown with recommended fertilizer + lime $+\mathrm{Mg}+\mathrm{B}$. The second highest grain yield was resulted from recommended fertilizer + lime $+\mathrm{Mg}$ treated plot which was statistically similar with recommended fertilizer + lime B treated plot. Harvest index of crop fully depends on grain yield and biological yield of crop. Harvest index of wheat was also significantly affected by treatment effect. The highest harvest was obtained when the crop grown with recommended fertilizer + lime $+\mathrm{Mg}+\mathrm{B}$ which was statistically similar with recommended fertilizer $+\mathrm{Mg}+\mathrm{B}$ and recommended fertilizer treated plot.

Table 3. Yield and yield attributes of wheat as affected by lime, Mg and B

\begin{tabular}{|c|c|c|c|c|c|c|c|c|c|c|c|}
\hline $\begin{array}{l}\text { Treat- } \\
\text { ments }\end{array}$ & $\begin{array}{c}\text { Plants } \\
\mathrm{m}^{-2} \\
\text { (no.) }\end{array}$ & $\begin{array}{c}\text { Tillers } \\
\mathrm{m}^{-2} \\
\text { (no.) }\end{array}$ & $\begin{array}{c}\text { Spikes } \\
\mathrm{m}^{-2}\end{array}$ & $\begin{array}{c}\text { Plant } \\
\text { height } \\
\text { at } \\
\text { maturity } \\
(\mathrm{cm})\end{array}$ & $\begin{array}{c}\text { Spike } \\
\text { length } \\
(\mathrm{cm})\end{array}$ & $\begin{array}{c}\text { Spikelets } \\
\text { spike- }^{-1} \\
\text { (no.) }\end{array}$ & $\begin{array}{c}\text { Grains } \\
\text { Spike- } \\
\text { (no.) }\end{array}$ & $\begin{array}{l}1000- \\
\text { grains } \\
\text { weight } \\
\text { (g) }\end{array}$ & $\begin{array}{l}\text { Straw } \\
\text { yield } \\
\left(\mathrm{t} \mathrm{ha}^{-1}\right)\end{array}$ & $\begin{array}{c}\text { Grain } \\
\text { yield } \\
\left(\text { t ha- }^{-1}\right)\end{array}$ & $\begin{array}{c}\text { Harvest } \\
\text { index } \\
(\%)\end{array}$ \\
\hline $\mathrm{T}_{1}$ & 192 & $488 \mathrm{~b}$ & $278 \mathrm{c}$ & $98 \mathrm{~b}$ & $11.18 \mathrm{c}$ & $16.52 \mathrm{c}$ & $41.90 \mathrm{~b}$ & $50.99 \mathrm{c}$ & $6.42 \mathrm{c}$ & $3.45 \mathrm{c}$ & $34.95 \mathrm{ab}$ \\
\hline $\mathrm{T}_{2}$ & 235 & $634 \mathrm{a}$ & 348 a & $102 \mathrm{a}$ & $13.45 \mathrm{a}$ & $21.12 \mathrm{a}$ & $49.75 \mathrm{a}$ & $58.87 \mathrm{a}$ & $8.35 \mathrm{a}$ & $4.88 \mathrm{a}$ & $36.87 \mathrm{a}$ \\
\hline $\mathrm{T}_{3}$ & 213 & 599 a & $321 \mathrm{ab}$ & $101 \mathrm{a}$ & $12.35 \mathrm{~b}$ & $19.41 \mathrm{~b}$ & $44.02 \mathrm{~b}$ & $54.85 \mathrm{~b}$ & $7.74 \mathrm{~b}$ & $4.02 \mathrm{~b}$ & $34.21 \mathrm{~b}$ \\
\hline $\mathrm{T}_{4}$ & 215 & $542 \mathrm{ab}$ & 314 b & $100 \mathrm{a}$ & $12.40 \mathrm{~b}$ & $18.98 \mathrm{~b}$ & $47.23 \mathrm{a}$ & $57.20 \mathrm{ab}$ & $7.81 \mathrm{~b}$ & $3.94 \mathrm{~b}$ & $33.52 \mathrm{~b}$ \\
\hline $\mathrm{T}_{5}$ & 207 & 374 c & $240 \mathrm{~d}$ & $95 \mathrm{c}$ & $9.94 \mathrm{~d}$ & $14.69 \mathrm{~d}$ & $34.49 \mathrm{c}$ & $41.42 \mathrm{~d}$ & $4.99 \mathrm{~d}$ & $2.76 \mathrm{~d}$ & $35.63 \mathrm{ab}$ \\
\hline$\overline{\text { F-test }}$ & ns & ** & ** & ** & ** & ** & ** & ** & ** & $* *$ & Ns \\
\hline CV (\%) & 6.76 & 10.35 & 5.25 & 1.08 & 1.47 & 3.36 & 3.83 & 2.60 & 2.73 & 3.37 & 3.67 \\
\hline
\end{tabular}

Within a character in column, means followed by different small letter(s) significantly different at $1 \%$ and $5 \%$ level by DMRT and same small letter(s) or without letter are not significantly different at 1\% level by DMRT.

$\mathrm{T}_{1}=$ Recommended fertilizer $+\mathrm{B}+\mathrm{Mg}, \mathrm{T}_{2}=$ Recommended fertilizer + lime $+\mathrm{B}+\mathrm{Mg}, \mathrm{T}_{3}=$ Recommended fertilizer + lime $+\mathrm{Mg}$, $\mathrm{T}_{4}=$ Recommended fertilizer + lime $+\mathrm{B}$, and $\mathrm{T}_{5}=$ control (only recommended fertilizer). 
Several workers suggest that lime application in acid soil is beneficial for soil health and improving the upland crop yield (Lal and Mathur, 1989; Prasad, 1992). The beneficial effect of liming on irrigated rice yields also reported by Mukhopadhyay et al. (1984). Rahman et al. (2002) stated that application of liming increased the yield and yield components of both rice and wheat. They also found that soil $\mathrm{pH}$, available $\mathrm{P}$ and $\mathrm{B}$, exchangeable $\mathrm{Ca}$ and $\mathrm{Mg}$ contents in the soil were increased; resulting increased the grain yield of both rice and wheat. They also stated that Mg application increased wheat yield, but not increased rice yield.

\section{Yield and yield components of mungbean}

Yield and yield components of mungbean also significantly influenced by different treatments effect, plant population per $\mathrm{m}^{2}$ was not significantly influenced (Table 4). Data on Table 4 shows that the tallest plant was produced when the crop treated with recommended fertilizer B, which was at par with recommended fertilizer + $\mathrm{Mg}+\mathrm{B}$ treated plot. It was observed that the plant height of treatments $75 \%$ recommended fertilizer, recommended fertilizer $+\mathrm{Mg}$ and without fertilizer was not significantly influenced with each other. The highest total fresh weight of plant per $\mathrm{m}^{2}$ was found from recommended fertilizer B treated plot, which was at par with recommended fertilizer $+\mathrm{Mg}+\mathrm{B}$, recommended fertilizer $+\mathrm{Mg}$ and $75 \%$ recommended fertilizer treated plots. The lowest total fresh weight of plants per $\mathrm{m}^{2}$ was found from without fertilizer treated plot. Number of pods plant ${ }^{-1}$ was the highest when the plot treated with recommended fertilizer B. The second highest was recorded from recommended fertilizer + Mg + B which was at par $75 \%$ recommended fertilizer treated plot and the lowest was recoded from without fertilized plot. The tallest pod was recorded from recommended fertilizer B and the lowest was obtained from without fertilized plot. It was observed that there was no significance differences of pod length between the treatments recommended fertilizer $+\mathrm{Mg}+\mathrm{B}, 75 \%$ recommended fertilizer and recommended fertilizer $+\mathrm{Mg}$. Considering on seeds pod ${ }^{-1}$ the highest was found from recommended fertilizer B treated plot, which was similar to recommended fertilizer $+\mathrm{Mg}+\mathrm{B}$ treated plot and the lowest was resulted from without fertilizer plot. The heaviest 1000-seed and biological yield were found from recommended fertilizer $\mathrm{B}$ treated plot and the second highest was recorded from recommended fertilizer + Mg + B treated plots. The lowest was recorded from without fertilizer plot. Significantly higher and similar grain yield was found in recommended fertilizer $+\mathrm{Mg}+\mathrm{B}$, recommended fertilizer $\mathrm{B}$ and recommended fertilizer $+\mathrm{Mg}$ treated plots and the lowest was recorded from without fertilizer plot.

Table 4. Yield and yield components of mungbean as affected by fertilizers and residual effect of preceding crop (wheat)

\begin{tabular}{|c|c|c|c|c|c|c|c|c|c|}
\hline Treatments & $\begin{array}{c}\text { Plants } \\
\mathrm{m}^{-2}\end{array}$ & $\begin{array}{c}\text { Plant } \\
\text { height } \\
(\mathrm{cm})\end{array}$ & $\begin{array}{c}\text { Fresh } \\
\text { weight } \\
\text { of } \\
\text { plants } \\
\mathrm{m}^{-2}(\mathrm{~g})\end{array}$ & $\begin{array}{l}\text { Pods } \\
\text { plant }^{1} \\
\text { (no.) }\end{array}$ & $\begin{array}{l}\text { Pod } \\
\text { length } \\
\text { (cm) }\end{array}$ & $\begin{array}{l}\text { Seeds } \\
\text { pod }^{-1} \\
\text { (no.) }\end{array}$ & $\begin{array}{l}\text { 1000- } \\
\text { grains } \\
\text { weight } \\
(\mathrm{g})\end{array}$ & $\begin{array}{c}\text { Biological } \\
\text { yield } \\
\left(\mathrm{t} \mathrm{ha}^{-1}\right)\end{array}$ & $\begin{array}{c}\text { Seed yield } \\
\left(\mathrm{kg} \mathrm{ha}^{-1}\right)\end{array}$ \\
\hline $\mathrm{T}_{1}$ & 21.28 & $74.37 \mathrm{ab}$ & $151 \mathrm{a}$ & $24.18 \mathrm{~b}$ & $9.35 \mathrm{~b}$ & $11.2 \mathrm{ab}$ & $48.46 \mathrm{~b}$ & $3.98 \mathrm{~b}$ & $842 \mathrm{ab}$ \\
\hline $\mathrm{T}_{2}$ & 19.20 & $66.40 \mathrm{~b}$ & $114 \mathrm{ab}$ & $23.87 b$ & $8.56 \mathrm{~b}$ & $8.98 \mathrm{c}$ & $44.13 \mathrm{~d}$ & $2.31 \mathrm{~d}$ & $713 \mathrm{~b}$ \\
\hline $\mathrm{T}_{3}$ & 18.85 & 87.07a & $164 \mathrm{a}$ & $27.22 \mathrm{a}$ & $12.19 \mathrm{a}$ & $12.27 \mathrm{a}$ & $50.36 \mathrm{a}$ & $5.09 \mathrm{a}$ & 923 a \\
\hline $\mathrm{T}_{4}$ & 18.34 & $68.58 \mathrm{~b}$ & $135 \mathrm{a}$ & $14.62 \mathrm{c}$ & $9.12 \mathrm{~b}$ & $10.73 \mathrm{~b}$ & $46.17 \mathrm{c}$ & $3.33 \mathrm{c}$ & $783 \mathrm{ab}$ \\
\hline $\mathrm{T}_{5}$ & 19.45 & $59.95 b$ & $65 \mathrm{~b}$ & $12.12 \mathrm{~d}$ & $6.45 \mathrm{c}$ & $6.28 \mathrm{~d}$ & $41.50 \mathrm{e}$ & $1.77 \mathrm{e}$ & $527 \mathrm{c}$ \\
\hline F-test & ns & $*$ & $*$ & ** & $* *$ & $* *$ & $* *$ & $* *$ & $* *$ \\
\hline CV (\%) & 9.61 & 12.80 & 22.81 & 6.14 & 4.87 & 6.27 & 2.02 & 10.57 & 11.01 \\
\hline
\end{tabular}

ns $=$ Non significant $*$ \& $* *=$ Significant at $5 \%$ and $1 \%$ level

Within a character in column, means followed by different small letter(s) significantly different at $1 \%$ and $5 \%$ level by DMRT and same small letter(s) or without letter are not significantly different at 5\% level by DMRT.

$\mathrm{T}_{1}=$ Recommended fertilizer $+\mathrm{Mg}+\mathrm{B}, \mathrm{T}_{2}=75 \%$ of recommended dose, $\mathrm{T}_{3}=$ Recommended fertilizer $+\mathrm{B}$,

$\mathrm{T}_{4}=$ Recommended fertilizer $+\mathrm{Mg}$ and $\mathrm{T}_{5}=$ control (without fertilizers).

It was observed that the higher yield and yield components of mungbean was found from recommended fertilizers B treated plot, which were some times statistically similar to recommended fertilizers B + Mg treated plots and lowest was recorded absolutely from control plot. These results might be after application of lime in previous crop help to availability of B and $\mathrm{Mg}$ for plant uptake, which ultimately help to increase nodulation of mungbean, resulting increased yield and yield components of mungbean. Similar results related to the study also found by several workers (Bolanos et al., 1996; Rahman et al., 1999; O'Hara, 2001) who reported B is an essential micronutrient for the development and functioning of nitrogen-fixing root nodules in legumes. B and Mg are important nutrients for BNF and it was also reported by Giller (2001), Adjei et al. (2002). In case of absolutely control plot in preceding crop did not apply lime with 
recommended fertilizer as a result $\mathrm{pH}$ was very low (acidic), which can induce deficiency of some essential plant nutrients, for example $\mathrm{P}$ and Mo, which will lead to a reduction in the number and size of nodules and BNF (Marschner, 1995).

\section{Conclusion}

From the results it is concluded that yield and yield components of wheat were the highest recommended fertilizers + lime $+\mathrm{Mg}+\mathrm{B}$ treated plot and the second highest were recorded from recommended fertilizers + lime $+\mathrm{Mg}$ treated plot. The lowest was recorded in control plot (only recommended fertilized). In case of mungbean the highest was found from recommended fertilizer + B treated plot, which was limed in previously cultivated wheat crop and the lowest was recorded from control plot (without fertilized).

\section{References}

Adjei, M.B., Quesenbery, K.H. and Chambliss, C.G. 2002. Nitrogen fixation and inoculation of forage legumes. SS-AGR-56, Agronomy Department, Florida Cooperative Extension Service, Institute of Food and Agricultural Sciences.

(www1.foragebeef.ca/ \$Foragebeef/ frgebeef.n sf/all/ frg90/ \$FILE/ fertilitylegumefixation.p df)

Alam, M.K. 2006. Banglapedia (National Encyclopedia of Bangladesh): Acid soil. (http:// www.banglapedia.org/ httpdocs/HT/ A 0024.HTM).

BARC. 1984. Soil fertility analytical services in Bangladesh. Consultancy Report, Bangladesh Agricultural Research Project. Phase-II, BARC, Dhaka, Bangladesh.

BARI. 2006. Annual Report, 2005-06, Bangladesh Agricultural Research Institute, Joydebpur, Gazipur, Dhaka, Bangladesh. 30p.

Bodruzzaman, M., Lauren, J.G., Duxbury, J.M., Sadat, M.A., Welch, R.M., Elahi, N.E. and Meisner, C.A. 2005. Increasing wheat and rice productivity in the sub-tropics using micronutrient enriched seed. PP. 187-198. In: Micronutrients in South and South-east Asia. (Eds). Anderson, P., K. Junoo, Tuladhar, B. Krishna, Karki and L. Surya Maskey. Proc of an International Workshop, held at 8-11 Sept, 2005, Kathmandu, Nepal.

Bolanos, L., Brewin, N.J. and Bonilla, I. 1996. Effect of boron on Rhizobium-legume cellsurface interactions and nodule development. Plant Physiology, 110: 12491256.

Bolton, J. and Penny, A. 2009. The longevity of sodium, potassium and magnesium fertilizer's residual effects on the yield and composition of ryegrass grown on a sandy soil. J. Agrl. Sci., 91: 693-699. (http://journals.cambridge.org/action/ disp layAbstract?fromPage=online\&aid $=477283$ $6)$.

FAO/UNDP. 1988. Land resources appraisals of Bangladesh for agricultural development. Agro-ecological regions of Bangladesh. FAO Rome, Italy. (Report No. 2).

Fattell, N.A., Evans, C.M., Carpenter, D.J. and Brockwell, J. 2007. Residual effects from lime application on soil $\mathrm{pH}$, rhizobial population and crop productivity in dry land farming systems of central New South Wales. Aust. J. Exp. Agric., 47: 608- 619. (http:// www.publish.csiro.au/paper/EA06 070).

Giller, K.E. 2001. Nitrogen fixation in tropical cropping systems. Wallingford, $\mathrm{CAB}$ International, Wallingford, UK. 448p.

Gomez, K.A. and Gomez, A.A. 1984. Statistical Procedures for Agricultural Research. 2nd Ed., Wiley and Sons, Inc. New York, USA.

Gupta, U.C., Jame, Y.W., Campbell, C.A., Leyshon, A.J. and Nicholaichuk, W. 1985. Boron toxicity and deficiency: a review. Canandian J. Soil Sci., 65: 381-409.

Hunter, A.H. 1972. Laboratory and greenhouse techniques for nutrient survey to determine the soil amendments required for optimum plant growth. Soil Fertility Evaluation Implementation Project. N.C. State University, Raleigh, N.C.

Islam, M.A. 1995. A study on the Competitive ability of six varieties of wheat with weeds. Bangladesh Agril. Univ., Dept. Agron, MS Thesis, pp. 30-33.

Jackson, M.C. 1958. Soil chemical analysis, Prentice Hall Incorporation Eaglewood Cliffs. New York.

Kassab, O.M. 2005. Soil moisture stress and micronutrients foliar application effects on the growth and yield of mungbean plants. J . Agric. Sci., Mansoura University, 30: 247256.

Kochian, L.V., Hoekenga, O.A. and Pineros, M.A. 2004. How do crop plants tolerate acid soils? Mechanisms of aluminum tolerance and phosphorous efficiency. Ann. Rev. Plant Biol., 55: 459- 493.

Kumer, R., Madan, S. and Yunus, M. 1994. Effect of planting date on yield and quality of durum wheat varieties. Res. J. Haryana Agric. Univ., 24: 186-188.

Lal, S. and Mathur, B.S. 1989. Effect of longterm fertilization and liming on an Alfisoil on maize, wheat and soil properties-I. Maize and Wheat. J. Indian Soc. Soil Sci., 37: 717724.

Marschner, H. 1995. Mineral nutrition of higher plants. London, Academic Press, London. 889p.

Marufuzzaman, M., J ohansen, C., Bodruzzaman, M., Neogi, M.G., Bell, R.W. and Rumana 
Begum. 2010. Diagnosing nutrient limitations to lentil and chickpea in acid soils of Bangladesh. 19th World Congress of Soil Science (WCSS), Soil Solutions for a Changing World, 1-6 August 2010, Brisbane, Australia.

Mukhopadhyay, P., Halder, M. and Mandal, L.N. 1984. Effect of $\mathrm{CaCO}_{3}$ on the availability of $\mathrm{Al}, \mathrm{Mo}, \mathrm{P}, \mathrm{Ca}$ and $\mathrm{Mg}$ in waterlogged acidic rice soil. Agrochimia, 28: 125-132.

NCDACS (North Carolina Department of Agriculture and Consumer Services). 2011. Plant Nutrients: Soil pH. Raleigh, USA. (http:/ / www.ncagr.gov/ cyber/ kidswrld/ plan t/ nutrient.htm\#top).

O'Hara, G.W. 2001. Nutrition constraints on root nodule bacteria affecting symbiotic nitrogen fixation: a review. Aust. J. Exp. Agric., 41: 417-433.

Peoples, M.B., Ladha, J.K. and Herridge, D.F. 1995b. Enhancing legume N-fixation through plant and soil management. Plant Soil., 175: 83-101.

Peoples, M.B., Lilley, D.M., Burnett, V.F., Garden, A.M. and Garden, D.L. 1995a. Effect of surface application of lime and super phosphate to acid soils on growth and Nfixation by subterranean clover in mixed pasture swards. Soil Biol. Biochem., 27: 663671.

Prasad, R. 1992. Effect of lime on yield of soybean and nutrient availability in acid soil. J. Indian Soc. Soil Sci., 40: 377-379.

Rahman, M.A., Meisner, C.A., Duxbury, J.M., Lauren, L. and Hossain, A.B.S. 2002. Yield response and change in soil nutrient availability by application of lime, fertilizer and micronutrients in an acidic soil in a ricewheat cropping system. 17th World Congress on Soil Science (WCSS), 14-21 August 2002, Thailand.

(http:// citeseerx.ist.psu.edu/viewdoc/ summ ary?doi=10.1.16.1281).

Rahman, M.H.H., Arima, Y., Watanable, K. and Sekimoto, H. 1999. Adequate range of boron nutrition is more restricted for root nodule development that for plant growth in young soybean plant. Soil Sci Plant Nutr., 45: 287296.

Renukadevi, A., Savithri, P. and Andi, K. 2004. Residual effect of Sources and Levels of Boron application on Greengram (Vigna radiata L.) in Sunflower-Greengram cropping sequence. Madras Agric. J., 91: 394-398.

Rowell, D.L. 1994. Soil Science: Methods and applications. John Wiley and Sons, Inc., 605 Third Avenue, New York, USA, 350 p.

Sippola, J. and Ervio, R. 1977. Determination of boron in the soils and plants by the Azomethine-H method. Finn. Chem. Lett. pp. 138-140.

Srisa-ard, K. 2007. Residual effects of applied chemical fertilizers on growth and seed yields of sunflower (Helianthus annuus cv. high sun 33) after the harvests of initial main crops of maize (Zea mays L.), soybean (Glycine max L.) and sunflower (Helianthus annuus). Pak. J. Biol. Sci., 10: 59-63.

Thalooth, A.T., Tawfik, M.M. and Magda Mohamed, H. 2006. A Comparative Study on the Effect of Foliar Application of Zinc, Potassium and Magnesium on Growth, Yield and Some Chemical Constituents of Mungbean Plants Grown under Water Stress Conditions. World J. Agric. Sci., 2: 37-46.

Walkley, A. and Black, A. 1934. An examination of the Degtjareff method for determining soil organic matter and proposed modification of the chromic acid titration method. Soil Sci., 37: 29-38.

Warren, G.P. 1992. Fertilizer Phosphorus: sorption and residual value in tropical African soils. NRI Bulletin 37, Charthan, U.K. Natural resources Institute. 89p.

ZARI (Zambia Agricultural Research Institute). 2011. Researching soils, crops and water: Soil fertility research (Management of acid soil for soybean production). Mt. Makulu Central Research Station Private Bag 7, Chilanga,Zambia. (http://www.zari.gov.zm/soil_fertility_rese arch.php) 